\title{
Vybrané metody sociální práce s dětským pacientem
}

\section{Dagmar Pitnerová}

\begin{abstract}
Abstrakt
V příspěvku se zabýváme přičinami přijetí dětí na dětská oddělení psychiatrických nemocnic, složením odborného týmu a jeho úkolech v době hospitalizace dítěte. Neméně důležité $v$ péči o dětského pacienta je zajištění ochrany jeho práv, která jsou ukotvena v príslušné legislativě. Představujeme nejčastější metody sociální práce s dětským pacientem, kterými jsou rozhovor, pozorování a dětská kresba. Př́padová studie „Tomáš“ je ukázkou systematické práce sociální pracovnice s dětským pacientem, která je charakterizována především expresivní komunikací, podněcováním, povzbuzováním, nasloucháním, vyjadřováním emocí, péčí a podporou.
\end{abstract}

Klíčová slova: dětský pacient, porucha, odborný tým, sociální pracovnice, rozhovor, pozorování, dětská kresba.

\begin{abstract}
In the paper, we deal with the root causes of adoption of children in the children's department of psychiatric hospitals, the provision of a specialist team and its tasks in the context of the child's hospitalization. Equally important in the care of a child patient is to ensure protection of the child's rights that are anchored in the relevant legislation. We present the most common methods of social work with children's patient as follows: an interview, an observation and a child's drawing. A case study of "Thomas" is an example of systematic work of a social worker with the child patient, which is characterized by especially expressive communication, encouraging, promoting, listening, showing emotions, care and support.
\end{abstract}


Keywords: children's patient, disorder, expert team, social worker, interview, observation, child's drawing.

\section{Úvod}

Osudy dětských pacientů, kteří se ocitli v situacích, kdy ani rodina, škola, kamarádi jim nemohli pomoci, jsou předmětem řady výzkumů. Je smutné, že se děti ve svém věku potýkají s problémy, které nedokážou překonat, zvládnout bez odborného zásahu dětských psychologů, lékařư, zdravotnických pracovníků, sociálních pracovnic a dalších odborníků. V průběhu individuálního vývoje každého dítěte se mohou objevit psychické poruchy, které jsou příčinou jeho hospitalizace na dětském oddělení psychiatrické nemocnice.

\section{Př́ččny hospitalizace dítěte}

Poruchy chování dítěte se mohou objevit na úrovni školy, rodiny nebo mezi vrstevníky. V případě, že se u dítěte nějaké obtiže objeví, je nutné nejdříve navštívit příslušnou pedopsychiatrickou ambulanci. Akutní psychiatrické vyšetření vyžadují stavy, kdy dítě náhle halucinuje, je zmatené, neklidné, nadměrně a dlouhodobě smutné, depresivní, podivínské nebo nepřiměřené ve svém chování a nápadných změnách jeho povahy (Matýs, 2014). Cílem akutního vyšetření při naléhavých psychiatrických stavech je stabilizace stavu pacienta. To znamená, že nejdříve je třeba zvládnout aktuální, často ohrožující chování, teprve potom je možné přikročit k dalšímu vyšetření, stanovení diagnózy a dalšího postupu terapie (Spousta, 2007). Důvody hospitalizace jsou jak diagnostické, tak terapeutické. Dětská oddělení psychiatrických nemocnic (dále PN) přijímají pacienty zejména s těmito diagnózami: psychotické poruchy, neurotické poruchy, emoční poruchy, úzkostně fobické poruchy, hyperkinetické poruchy chování, mentální retardace s poruchou chování, poruchy školních dovedností, poruchy příjmu potravy, zneužívání návyk. látek, vztahové poruchy, sebevražedné nebo sebepoškozující jednání, poruchy autistického spektra.

Problematice nárůstu psychických problémů u děti se věnoval Theiner (2009) a uvádí př́ičiny, které je způsobují: tlak rodiny a školy na výkon, krize modelu rodiny, nárůst sociálně patologických jevů, týrání, zneužívání, životní styl a moderní trendy. Zvyšování počtu těchto potíží je podle něj také spojeno s tím, že moderní medicína dokáže zachránit podstatně větší počet dětí, které se rodí předčasně a nezralé s vrozenými vadami a handicapy, u nichž se mohou později objevit psychické poruchy či mentální retardace. Trvale se zvyšuje výskyt poruch příjmů potravy a dětí se specifickými poruchami učení nebo s hyperkinetickými poruchami. 
Jedním z nejdůležitějších úkolů pro rodiče je zajistit, aby dítě bylo $\mathrm{k}$ léčbě svých potiží dostatečně motivováno. Je žádoucí, aby spolupráce byla založena na dobrých základech informovanosti, a to nejen rodičů, ale i dítěte samotného. Často se stává, že rodiče odkládají seznámení dítěte s jeho nemocí, a to není pro jeho vývoj zcela v pořádku (Řičan \& Krejčírová, 1995).

\section{Systém péče o ohrožené dítě}

Klient - dětský pacient je přijímán k hospitalizaci na doporučení pedopsychiatra v situaci, kdy již není možné saturovat jeho zdravotní stav ambulantní cestou.

\subsection{Práva dítěte v období hospitalizace}

U dětského pacienta je nutné dodržovat jeho práva, která jsou zakotvena v Úmluvě o právech dítěte. Dítě má právo na zvláštní péči v závislosti na rozsahu existujících zdrojů. Právo dítěte je zajištováno př́slušnými orgány, kterým bylo dítě svěreno do péče, jedná se o jeho léčbu, ochranu tělesného či duševního zdraví, pravidelné hodnocení zacházení s dítětem a všech dalších okolností spojených s jeho umístěním (článek 23, 25). Následně je v Zákoně č. 372/2011 Sb. o zdravotních službách a podmínkách jejich poskytovánív $\S 46$ odst. 1 písm. b) uvedeno, že poskytovatel zdravotních služeb je povinen zajistit sestavení, koordinaci a realizaci individuálního léčebného postupu a komplexnost, návaznost a koordinovanost poskytovaných zdravotních služeb. Je tréeba tedy zajistit poskytnutí těchto informací dítěti, zákonnému zástupce, prípadně oprávněným osobám, uvedeným $v$ tomto zákoně $v \S 42$. Je nutné rozlišovat mezi souhlasem s hospitalizací a souhlasem s péćí. § 31 a 35 tohoto zákona hovoří o tom, že nezletilému pacientovi poskytneme informace a zodpovíme doplňujíci otázky, je-li k takovému úkonu přiměřeně rozumově a volně vyspělý.

Charta práv dětí v nemocnici, kterou vydala Centrální etická komise Ministerstva zdravotnictví České republiky, uvádí, že děti mají být přijaty do nemocnice, až tehdy, pokud jim nelze poskytnout adekvátní péči v domácím prostředí nebo při ambulantním docházením. Dále hovoři o právu dětí na neustálý kontakt se svými rodiči a sourozenci a právu na informace v takové podobě, která odpovídá jejich věku a chápání. Charta dále uvádí, že děti a nebo jejich rodiče musí mít právo poučeně se podílet na veškerém rozhodování ohledně zdravotní péče, která je jim poskytována. 


\subsection{Dětská oddělení psychoatrických nemocnic}

Dětská oddělení PN jsou považována za zdravotnická zařízení lůžkové péče, které jsou určené k poskytování péče dětem, jež trpí duševní poruchou (Čevela, Čeledová, 2010). Dětem, u nichž byla diagnostikována akutní duševní porucha nebo akutní dekompenzace duševní poruchy chronické (Marková a kol., 2006).

Uvedená zařízení poskytují komplexní pedopsychiatrickou, psychologickou a psychoterapeutickou péči a zároveň jsou akreditovanými pracovišti dětské psychiatrie a dětské klinické psychologie. Zajištují diagnosticko-léčebné pobyty pro celou škálu psychických poruch v oblasti dětské a dorostové psychiatrie. Především se jedná o poruchy a aktivity a pozornosti, poruchy chování, problémové chování u dětí s mírnějším stupněm mentální retardace, poruchy nálady, neurotické a tikové poruchy, vztahové problémy, psychózy schizofrenního okruhu, poruchy autistického spektra, problémy spojené s experimenty a abusem návykových látek, krizové intervence, podezření na týrání či zneužívání, poruchy př́immu potravy a mnoho jiných.

Dětské oddělení poskytuje především péčí intramurální, tedy poskytovanou v institucích typu psychiatrické nemocnice a léčebny. Psychiatrická zařízení jsou většinou zřizována jako samostatná pracoviště nebo jako součást vyššího zdravotnického zařízení. Každopádně základním cílem je, aby v každém regionu České republiky byla potřebná nabídka služeb, jak v oblasti psychiatrické, tak psychologické, psychoterapeutické či v oblasti sociálních služeb (Marková a kol., 2006).

Děti v průběhu pobytu na dětském oddělení PN navštěvují ZŠ a MŠ praktickou a speciální, jsou vzdělávány formou individuální výuky ve spolupráci s jejich původní školou. Volný čas na dětském oddělení PN je organizován a probíhá pod vedením dětských sester, vychovatelů, speciálních pedagogů a psychologů. Děti jsou rozděleny dle skupin podle aktuálního zdravotního a psychického stavu, věku a schopností. Denně děti chodí na procházky ven, kontakt s rodinou mohou mít vždy v určenou dobu, návštěvy a vycházky nesmí narušovat terapii, školní výuku a režim oddělení. Víkendovou dovolenku mají cca $1 \times$ za měsíc po domluvě s lékařem.

\subsection{Odborný tým}

Dětská oddělení PN nabízejí pro dětské pacienty širokou péči: komunitní systém, režimová opatření, individuální, skupinové a rodinné psychoterapie, autogenní trénink, etopedické skupiny, rehabilitace, školní přípravu pod dohledem vychovatelů nebo zdravotnických pracovníků. Důraz je kladen především na spolupráci s rodiči nebo zákonnými zástupci dítěte.

Každému dítěti je poskytnut individuální přístup, které vede k všestrannému harmonickému rozvoji dítěte, a který je zajištován odborným týmem. 
Odborný tým je sestaven z psychologů, lékařů, sociálních pracovníků, zdravotnických asistentů a dětských sester se středoškolským, vyšším odborným nebo vysokoškolským vzděláním zdravotnického či speciálněpedagogického směru, a z nižších pomocných zdravotních pracovníků a vychovatelek. Každý pracovník by měl disponovat nejen určitými znalostmi, schopnostmi a dovednostmi, ale musí dodržovat také určité etické principy (Kutnohorská a kol., 2011). Hlavním cílem odborného týmu zajištění kvalitní péče o dětské pacienty trpící duševní poruchou. Základní předpokladem je vzájemná spolupráce jednotlivých členů. Povinností psychologa je komplexní i cílená diagnostika, individuální, skupinová a rodinná psychoterapetuická péče, účast na prijímání dětí na oddělení prostřednictvím podrobného pohovoru s rodiči, účast na denních aktivitách dětí (vizity, komunity, hodnocení) a spolupráce se školou při psychiatrické nemocnici, s kmenovými školními institucemi, s pedagogicko-psychologickou poradnou. Mezi činnosti vychovatele patří výchova, vzdělávání, terapie, diagnostika, reedukace a resocializace dětí a mládeže (Sekera, 2009). Etoped se zabývá diagnostikou a výchovným poradenstvím. V resortu zdravotnictví pracuje jako učitel škol při psychiatrických léčebnách či léčebných ústavech (Spousta, 1995). Dětská sestra je významným členem zdravotnického týmu, spolupracuje s lékařem v oblasti léčebně preventivní péče, vyhledává a uspokojuje základní potřeby nemocných.

Důležitou součástí odborného týmu dětského oddělení jsou také sociální pracovníci, kteří mají za úkol pomáhat dětem, jejich rodinám k návratu do jejich přirozeného prostředí, snaží se o vytvoření vhodných společenských podmínek (Matoušek, 2003). Sociální pracovník by měl disponovat znalostmi z různých oborů, měl by zvládnout diagnostikovat problém a řešit situaci klienta, zároveň sociální pracovník odkazuje klienta na př́slušné odborníky (Gulová, 2011).V sociální práci je stěžejní sociální diagnóza, která spočívá především v získání klíčových informací o situaci klienta a jejich zhodnocení.

\section{Obrázek 1}

Propojení spolupráce sociální práce ve zdravotnictví (Kuzníková, 2011, str. 24).

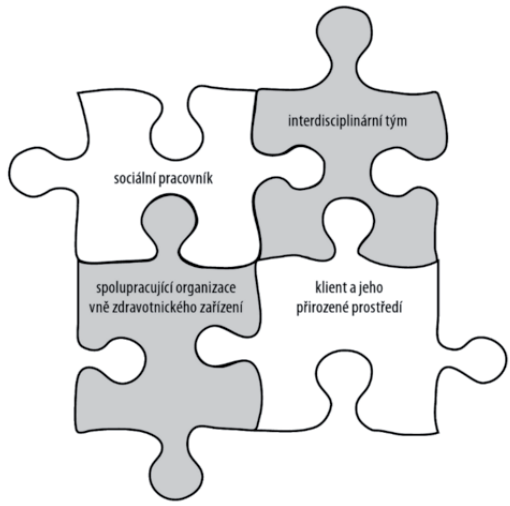


Hluboká empatie umožní lépe pochopit pocity dětského klienta, což pomůže sociálnímu pracovníku pracovat efektivně a profesionálně (Gulová, 2011). Bezpodmínečný je také zájem o dětského pacienta a respektování jeho osobnosti. Sociální pracovník by také měl umět přijímat dětského pacienta bez předsudků, pracovat s ním ve vztahu, který je založený na důvěře, respektu. Měl by dodržovat několik principů. V prvé řadě by měl v průběhu doprovázení s dítětem hovořit srozumitelně, naopak by neměl mluvit o věcech, které nemá ověřené.

\subsection{Diagnostické metody v sociální práci}

Sociální práce však není všemocný a společnost nemá dostatek prostředků, aby se vyrovnala se všemi nepříznivými sociálními jevy. Proto je třeba sociální problémy kvalitně diagnostikovat a poté určit, kam omezené zdroje zacílíme.

Diagnóza v sociální práci je postavena na pořízení klíčových informací o sociálních problémech klienta a jejich zhodnocení.

Při pořizování základních informací získává sociální pracovník informace jako jsou: identifikační údaje (jméno, datum, narození, adresa atd.), důvod k sociální práci (zjevný, popř. skrytý problém), rodinné pozadí klienta (rodinný vztah, vztah k členům rodiny, sociální pozadí klienta (blízcí lidé, společenské postavení), tělesný stav klienta (zdraví a hygiena), intelekt a dosažené vzdělání, emocionální chování (temperament a navykle chování a jednání), schopnost řešit problémy, ekonomická situace klienta, bydlení klienta (příp. dopravní prostředek, kterým cestuje do práce), podmínky stravování klienta a jeho osobní bezpečí a celkový dojem z klienta. Všechny informace, které získá, musí být objektivní, úplné a přehledné.

Jednou ze základních diagnostických metod je rozhovor. Komunikace s dětským pacientem je vždy specifická. Prvním předpokladem úspěšné komunikace je důkladná znalost vývojových charakteristik a zvláštností každého vývojové období jedince od narození až do adolescence. Dále je komunikace bezprostředně podmíněna zdravotním stavem, charakterem a typem onemocnění a intenzitou klinických příznaků. Ovlivňuje ji také momentální prožívání a psychický stav dítěte. V kontaktu s ním se sociální pracovník stává partnerem ve hře, náhradou za kamarády i rodiče (Venglářová, Mahrová, 2006).

Komunikace s dítětem a jeho rodiči vyžaduje opravdu velkou dávku trpělivosti, důslednosti, upřímnosti, lidskosti a schopnosti naslouchat. Důležité je i profesionální vystupování. Při komunikaci s dětským pacientem platí především to, že sociální pracovník naslouchá nejenom sluchem, ale i zrakem, kdy sleduje prvky neverbální komunikace a současně může projevovat empatii (Matějček, 2001). Při komunikaci s dětmi jim sociální pracovník zdůrazňuje, že jejich pocity jsou důležité, že mají právo se podílet na záležitostech, které se jich týkají. Plně si uvědomuje, že pro děti často není jednoduché mluvit o prožitých skutečnostech a navíc děti někdy ani neví, jak mají situaci slovy popsat, nebo se za ní stydí. Spontánně se děti vyjadřují pomocí těla, kresby či hry. 
Při rozhovoru s dítětem sociální pracovník nepokládá sugestivní otázky, nezpochybňuje ani nebagatelizuje to, co dítě sdělilo, neptá se znovu na věci, které již byly řečeny. Sociální pracovník dítěti pokládá otázky jednoznačně a srozumitelně, dle jeho věku a schopnosti. Nikdy se dítěte neptá na důvod, PROČ se to či ono stalo. $V$ průběhu rozhovoru dítě nekritizuje nebo nehodnotí negativně. Pokud je kritika třeba, vždy kritizuje věc, čin dítěte, ne samotné dítě. Je důležité dítě ocenit, že je prítomno, že se svěřilo a že spolupracuje. Spciální pracovník by měl být rovněž připraven na citové reakce dítěte, schopen vyjádřit mu soucit (Dobrušová, 2012).

Pozorování přináší sociálnímu pracovníkovi rovněž velké množství informací o vnitřním stavu dětského pacienta. Pozorování je záměrné, cílevědomé a plánovité sledování smyslově vnímatelných jevů (Šnýdrová, 2008). Ve zdravotnictví je používáno pravidelně, aniž by si toho dětský pacient musel nutně všimnout. Výsledek pozorování však vždy záleží na sociálním pracovníkovi, jak posoudí skutečnost a jaké závěry vyvodí. Při pozorování by měl vnímat i citlivost dítěte, jeho citovou reaktivitu a úroveň adaptability Úkolem pozorování je především dobře poznat dětského pacienta jako osobnost, jeho sociální prostředí, jeho motivační a hodnotový systém (Zacharová, Hermanová, Šrámková, 2007).

Třetí metodou sociální práce využívanou sociálními pracovníky na dětských odděleních PN jsou kresby. Kresba je pro dítě přirozený prostředek sebevyjádření, jak mohou děti zobrazit svůj reálný a fantazijní svět a zároveň je to jeden z nejvhodnějších způsobů, jak poznat jeho osobnost. Dětská kresba odkrývá vnitřní život dítěte, jeho myšlení, vnímání, cítění a rovněž vypovídá o jeho rozvoji v mnoha oblastech. Děti kreslí na základě svého prožitku a jsou motivovány aktuálním vnímáním situace. Do kreslení promítají své nitro, svá nevědomá i vědomá přání. Kreslení je činnost, která je pro děti zcela přirozená, zábavná a dítě do ní nemusíme nutit. Kresba může sloužit jako výchovný, poznávací, vzdělávání a formativní nástroj. Je to ale také prostředek komunikace a socializace. Kresba může poskytnout informace v mnoha oblastech osobnosti dítěte. Jednou z nich je vývojová úroveň dítěte. V kresbě nacházíme určité znaky, které právě souvisí s chronologickým věkem normálně se vyvíjejícího dítěte. $V$ každém vývojovém stádiu najdeme určité znaky a prvky, které by se v kresbě měly vyskytovat. Kresba tak může poukázat na individuální odlišnosti, může odhalit nerovnoměrnosti a odchylky ve vývoji, na rozumový vývoj žáka, protože děti kreslí zásadně to, co znají. Kresba je i důkazem úrovně rozvoje jemné motoriky a grafomotoriky, zrakového a prostorového vnímání. Dítě určitého věku by totiž mělo umět rozlišovat podstatné znaky předmětů a využívat prostor. Kresba rovněž vypovídá o uspořádání života dítěte, podle toho, jak má uspořádanou kresbu v prostoru. Při diagnostickém procesu dětské kresby musíme na obrázku sledovat určité prvky, z nichž některé jsou více a některé méně důležité. Důležité je najít ty, které mají tu hlavní výpovědní hodnotu. Mezi jedenáct znaků, které bychom měli $v$ dětské kresbě sledovat patři téma kresby, přiměřenost kresby $k$ věku kreslícího jedince, provedení kresby, linie kresby, využití plochy, figurální kompozice, 
problémové momenty v kresbě, volba a využití barev, kvalita kresby, čas potřebný k provedení kresby, kolektivní kresba. Kresba je rovněž ukazatelem grafomotorických a senzomotorických schopností dítěte, odráží jeho vnímání světa, neuspokojené potřeby, ale také jeho touhy a přání, vypovídá i o jeho rodinném prostředí (Cognet, 2013).

Dítě, které trpí nějakou psychotickou poruchou, své postižení projeví v kresbě už v průběhu svého vývoje. Tyto děti bývají často uzavřené do sebe, kde si žijí ve svém uzavřeném vnitřním světe. Mezi typické znaky kresby pak patří spirály, mnoho čar, které připomínají koleje, schodiště, pavučiny, žebř́ky a ploty. Pokud děti kreslí předměty, tak jsou různorodé, postavené vedle sebe bez jakéhokoliv vztahu a dítě je dokola mnohokrát obkresluje, aby je oddělilo, čímž dává najevo svůj pocit odcizení od světa. Svými obrázky tyto děti dávají najevo určitou atmosféru - pochmurnou, veselou, agresivní a celý ten obrázek je strnulý. Čáry jsou zřetelné, silné, geometrické a projevuje se cit pro stylizaci. Když dítě domaluje, dává najevo konec bud'šikmou čárou nebo do dolní části napíše slovo „konec”.

V procesu mapování situace dětského klienta se může stát, že klient bude pochybovat o možnostech pomoci, bude pomoc odmítat nebo ji nebude důvěřovat. V každém případě je povinností sociálního pracovníka pokusit se navázat s klientem důvěrný vztah a vysvětlit mu všechny možnosti, které mu Ize nabídnout (Kuzníková, 2011). Sociální pracovník při výkonu svého povolání pracuje nejen se samotným dětským pacientem, ale i s jeho rodinou, školou, orgány sociálně právní ochrany, pedagogicko-psychologickými poradnami, speciálněpedagogickými centry, s Policií ČR, dětskými domovy, výchovnými ústavy, domy na půli cesty, probační mediační službou aj. Konkrétní postupy a zásahy sociálního pracovníka jsou velmi výrazně ovlivněny typem a povahou onemocnění, či znevýhodněním dětského pacienta, akutností či chronicitou nemoci a rovněž formou poskytované péče, zda se jedná o péči ambulantní či ústavní. Cílem sociální práce je intenzivní spolupráce s rodinou dětského pacienta, jeho možný návrat do původního prostředí, pokud je ovšem toto prostřední funkční a vyhovující.

\section{Príklad případové studie dětského pacienta}

Př́padová studie demonstruje potřebnost týmové spolupráce, individuálního přístupu k dětskému pacientovi s ohledem na jeho práva, důležitou úlohu sociálního pracovníka při práci nejenom s dětským pacientem, ale i jeho rodinou, školou, orgánem sociálně právní ochrany dětí a dalšími institucemi.

\section{Prípadová studie TOMÁŠ ${ }^{1}, 8$ let}

Abusus: kouřil $1 \times v$ jejich domě, vzal od bratra, kterému je 15 let a kouří, nechutnalo mu, alkohol nezkoušel.

\footnotetext{
1 Jméno bylo změněno.
} 


\section{Rodinná anamnéza:}

Matka (nar. 1972), základní vzdělání, nezaměstnaná, vedena na ÚP, kuřák. Matka zemřela v 63 letech, infarkt, otec zemřel v 70 letech, zápal plic, měl dva sourozence starší bratr zemřel při autonehodě, mladší sestra trpí duševní poruchou.

Otec (nar. 1971), základní vzdělání, žije jako bezdomovec, se synem je v kontaktu, výživné neplatí, kuřák, alkohol požívá pravidelně ( $2 \times$ nastoupil léčbu v PN, nikdy nedokončil). Matka 62 let, ráda si vypije, otec zemřel v 72 letech.

Tomáš má tři sourozence, dva bratry (15 let a 12 let) a sestru (11 let), všichni jsou zdrávi. Tomášovi rodiče byli manželé čtyři roky, žili společně po rozvodu 10 let, nyní bydlí dva roky odděleně. Od počátku jejich soužití manžel hodně pil.

Školní anamnéza: MŠ nenavštěvoval, 2 roky přípravky - problémy s chováním nebyly, měl odklad školní docházky, nyní v 1. třídě ZŠ. Dle matky nechce psát domácí úkoly, nutí svou starší sestru, aby psala za něj, jinak jí vyhrožuje. Problémy s chováním vưči dospělým nemá.

Zdravotní anamnéza: Čtvrtá gravidita, porod iniciován, záhlavím. Poporodní adaptace přiměřená. Byl neklidný, dle matky divný od počátku, hodně se vztekal, bylo na něm vidět, že „není normální“. Do čtyř let vůbec nemluvil, vydával jen hrdelní zvuky. Vzpurný, zlý, stále jen křičel. Chodit začal v jednom roce, tělesnou hygienu udržuje od 4 let. Vážněji nemocen nebyl, sledován na kardiologii - šelest na srdci - kontroly $1 \times$ ročně. Úrazy: drobná poranění, nyní v nemocnici na JIP - spadl ze 3. patra (matka si měla zavolat pro výsledky, ale neudělala to). Alergie nezjištěna.

Při prijietí: kontakt navazuje ochotně, orientován plně, oční kontakt udržuje, odpovědi přiléhavé, dosti obsažné, místy se sám ptá, v řeči nevyslovuje ř - na výzvu ho ríct umí, emočně plošší, deprivace, myšlení koherentní, osobnost dětská, nic psychotického, popsány afektivní záchvaty s verbální a brachiální agresivitou, nerespektování matky, zjevně nedostatečné výchovné vedení, nepodnětné prostředí, chybí denní režim, rodinná neúplná, otec bezdomovec.

Sociální anamnéza: Tomáš je na dětském oddělení PN hospitalizován poprvé. K hospitalizaci byl odeslán z ordinace pro dětskou a dorostovou psychiatrii s diagnózou porucha chování $v$ rodině. $K$ vyšetření byl doporučen praktickou lékařkou, protože je dle matky „....vzteklý, agresivní a sprostý. ${ }^{\prime} V$ dorostové psychiatrické ambulanci klidný, hyperaktivita nezpozorována, v kontaktu bezprostřední, bez psychotických, neurotických i organických projevů. Matka trvala na diagnostickém pobytu, nebot' „....nemá klid od doby, co se narodil, musí být po jeho vưli."

\section{Situace před hospitalizací:}

V říjnu 2014 bylo provedeno psychologické vyšetření pedopsychologem s tímto závěrem: U chlapce nezjištěny výrazné abnormity, poškozen dysfunčkním rodinným prostředím, s nízkou socioekonomickou úrovní, výchovně zanedbán, nestimulován. Intelektové schopnosti odpovídají pásmu výrazného podprůměru, podíl nepodnětné prostředí, insuficientní výchovné vedení rodiči, kde je potřeba zvážit rodičovské schop- 
nosti a kompetence matky, která mě děti v své péči. Matka je vulgární, vše o životě v partnerském vztahu ventiluje před dětmi. Spolupráce s matkou je velmi obtížná, na domluvené termíny se dostavuje jen sporadicky.

Na žádost matky poslán do dětské a dorostové psychiatrické ambulance. Kde po komplexním vyšetření psychiatrem, rozhovoru s pacientem a matkou byla diagnostikována Porucha chování v rodině - F91. Následně matka požadovala, aby byl syn Tomáš odeslán na diagnostický pobyt do PN. Na základě lékařské zprávy z dětské a dorostové psychiatrie byl Tomáš pozván k přijetí do PN v březnu 2015.

Sociální pracovnice Orgánu sociálně právní ochrany dětí příslušného úřadu (OSPOD), sdělila, že rodina je delší dobu sledována, nebot' starší bratr (15 let) byl umístěn do dětského domova se školou ve 12 letech z důvodu výchovných (problémy s nerespektováním dospělých, vysoká neomluvená absence ve škole). Chlapec se zlepšil v klidném prostředí dětského domova. Ústavní výchova však nadále trvá. Z opatrovnického spisu vyplývá, že matka byla vždy vulgární, péči nezletilým dětem se snažila zajištovala dle svých schopností a možností. Nejdříve byla vulgární pouze k manželovi, poté její hněv a vulgarismy přešly také k dětem. Matka odmítá jakékoli odborné poradenství, aby změnila chování ke svým dětem. Odmítá také navštívit psychologa.

\section{Hospitalizace Tomáše na dětském oddělení v březnu 2015:}

Tomáš prí prijetí v rámci rozhovoru se sociální pracovnicí uvedl: Je mu 8 let, adresu (na dotaz) sdělil přesně, doma bydlí s matkou, dvěma bratry a sestrou. Bratry má rád, nadává sestře a matce. Neví, proč jim nadává moc sprostě. Doma se mu nelíbí, že mamka jenom leží, že si ani nejde s ničím hrát, a tak. Má rád strouhanku s vodou a cukrem, když mu matka nechce dát, tak ji nadává. Jednou sestře rozbil nos, tekla jí krev. Líto mu to bylo (ale usmívá se), pak mu sestra dala „bombu“ do zad.

Chodí do 1. třídy, ve škole mu to jde dobře. Připouští, že úkoly mu někdy nejdou, jinak mu z toho něco jde. Ve škole ho baví hračky, z učení pak matematika - mají krtka, ten se mu líbí. Kamarády ve škole má. Na otázku, zda ve škole zlobí, odpovídá, že jen o přestávkách dělají s kluky blbosti. Doma se převleče, počká na jídlo, nají se, podívá se na televizi a jde ven. Venku si hraje s kámošem. Mají stejné plyšáky, vezmou si je ven a hrají si. Domů chodí večer nebo ráno, prý byl někdy i v noci venku. Mamka mu někdy řekla, v kolik má přijít, ale přišel pozdě, hodinky má rozbité. Do kroužků nechodí. Mamka, když je naštvaná, ho trestá tak, že ho praští do zad. Je pravda, že sestru praštil kladívkem do hlavy, neví co se jí stalo, už je to dávno, i kvůli tomu je tady. V noci se mu nespí dobře, nechce se mu. V kolik chodí spát neví. Ničeho se nebojí, náladu má dobrou. Při rozhovoru se postupně uvolnil, choval se bezprostředně, neměl problémy s autoritou sociální pracovnice.

Matka při prijetí uvedla: Když byl Tomáš malý, velmi ho lákala světla, chtěl být pořád venku a dívat se na světla, matka jej tahala domů, že taky mají žárovky, hračky ho vůbec nezajímaly, s ničím si nehrál, houpal se, nebo třeba boty pořád řadil do řad, když mu to změnili, tak vztek. Když v jeho útlém dětství otec byl propuštěn z výkonu trestu a přišel 
domů, tak měl záchvat, že je tam někdo nový. Dlouho nechtěl nosit kalhoty, rifle, byl ochoten jen v teplácích nebo kratasech, ted' do školy ho matka donutila. Doma nevydrží, matka ho musí vypustit ven v jakoukoli hodinu, jinak je nesnesitelný, stále ho upomínají, co má dělat, na to on po nich řve. Nechce být doma. Doma dle matky "hrůza", chová se jako postižený, stále se vzteká, velké výkyvy v emocích, když se mu s něčím nevyhoví, když se neudělá, co chce on. Matka mu musí třeba dělat "kapučíno“ ve 4 hodiny ráno, kdy chlapec vstane, jinak všude rozsvítí, dělá kravál a budí ostatní. Když se vzteká, tak si lehne na zem, bouchá do všeho, rozbíjí, ničí. Stále všem okolo nadává, doma i venku, ale jen lidem, které zná, na cizí si netroufne. Křičel z balkónu. Krade doma peníze, sbírá sklínky od piva, za to si kupuje lízátka. Nejraději je venku celý den, je schopen jít i bosky, když nedostane boty, venku si chvilku hraje s ostatními, ale nevydrží to, pak je sám, toulá se nebo jde přes cestu do obchodu. Lidi a děti venku si na něj hodně stěžují. Dle matky je taky hodně lehce zmanipulovatelný. Venku všechno sbírá, např., „vajgly“, taky se potuluje okolo obchodu a třeba najde vypadnutou krabičku cigaret apod. Umí být i milý, ale vydrží jen pár minut. Zklidní se jídlem, pitím. Koníčky chlapce: rád jí, chodí ven, kde se toulá do noci, někdy ani ze školy nepřijde domů, matka jej hledá. Běžně se toulá do 22-23 hodin v noci. Rád se dívá na TV (Disney channel), hledá věci, stále chodí a dívá se okolo sebe.

Po prijietí Tomáše na dětské oddělení $P N$ dochází k jeho vyšetření, vyplnění požadovaných formulářủ, nastavení režimu, dochází k dalšímu došetření. Vyžádán školní dotazník. Základní škola, kde dětský pacient dochází, uvádí, že jeho chování je naprosto bezproblémové. Ve vyučování plní pokyny, neobjevily se žádné negativní projevy chování. Ve výuce bylo nutné občas uplatnit individuální př́stup, ale za ten byl chlapec velmi vděčný. Podle ZŠ je chlapec živý, uzavřený a má rád pohybové dětské hry. Dle jejich sdělení je rodinné prostředí velmi nepodnětné. Matka se s chlapcem do školy nepřipravuje, zapomíná pomůcky, úkoly atd., někdy nemá ani jídlo a pití. Matka se o chlapci vyjadřuje velmi vulgárně. $Z$ jejich výroků usuzují, že o chlapce nemá zájem a chybí jí mateřská láska. Tomáš byl v rámci hospitalizace umístěn do základní školy při zdravotnickém zařízení a mateřské školy při zdravotnickém zařízení. Adaptace v novém prostředí u něj proběhla bez problémů, byl kamarádský, vstřícný, měl velmi pěkný vztah k mladším spolužákům. Nebyl vůdčí typ, mezi dětmi oblíbený, k dospělým slušný, milý, ochotný, autoritu dospělých plně respektoval. Ve vyučování se projevoval pomalejším tempem, často nutný individuální prístup, těžkopádný, výkony v hodinách narušovány projevy ADHD (psychomotorický neklid - poposedávání na židli, houpání nohama, pohyby celým tělem), obtížné a krátkodobé soustředění, snadno odklonitelná pozornost. Myšlení málo samostatné, složitější úkol zvládal s vedení po krocích. Po príjetí musela sociální pracovnice $P N$ dožádat učební pomůcky, přezůvky, teplé boty, ponožky a hygienické potřeby u odboru sociálních věcí, nebot matka sdělila, že chlapci přinese přezůvky, až bude mít peníze. $V$ průběhu hospitalizace se matka neustále domáhala diagnózy autismus (dokonce přistižena, jak syna instruovala, co má dělat, aby se pro- 
kázal jeho autismus). Po jednání s matkou sociální pracovnice PN sděluje, že matka se ve svých postojích jeví rigidní, neodklonitelná, není schopna spolupráce a výchovného vedení ke stabilizace vývoje. Během pohovorů konfrontační tendence, nekritičnost, vulgarizmy, útočnost. Dohled OSPOD nad výchovou a prospíváním dítěte po dimisi je zcela nezbytný. Je rovněž na zvážení, zda chlapec setrvá v rodině, aktuálně se jeví výchovné vedení chlapce matkou jako poškozující. Hospitalizace ukončena na žádost matky v květnu 2015. Dále doporučena pravidelná péče pedopsychiatra, dohled OSPOD nad výchovou dítěte.

Stanovená diagnóza: F91Poruchy chování - porucha chování vázaná na vztahy v rodině, emoční deprivace, výchovné zanedbání.

Sociální práce s Tomášem: Sociální pracovnice si po jeho přijetí na oddělení dala za cíl zajistit mu sociální potřeby (ekonomické zajištění - kapesné, rodinné kontakty kontakt s matkou, kontakty s ostatními institucemi - škola, pedopsychiatr, OSPOD) po dobu léčby a dopomoci mu k nejlepšímu sociálnímu fungování s ohledem na jeho základní diagnózu.

Po přijetí Tomáše se seznámila s jeho základní diagnózou, zdravotní dokumentací a aktuálním vývojem jeho zdravotního stavu. Následně svůj přístup přizpůsobila charakteru jeho onemocnění, přičemž v komunikaci s ním respektovala jeho autonomii a při rozhovoru zvolila takový způsob komunikace, kterému chlapec rozuměl. Při přijetí si sociální pracovnice odebrala sociální anamnézu od dětského pacienta i jeho matky. Rozhovor s matkou velmi komplikovaný, spolupráce s ní byla velmi složitá, až nemožná. Následně si vyžádala vyjádření OSPOD, školy a pedopsychiatra. Sociální anamnéza Tomáše je vedena v jeho sociálně kartě, včetně všech dalších kroků, které sociální pracovnice v jeho případě provedla (vše je vedeno, jak v písemné, tak v elektronické podobě). Sociální pracovnice byla plnohodnotnou členkou multidisciplinárního týmu PN, který o Tomáše pečoval. Sociální pracovnice spolu s rozhovorem využila metody kresby. Chlapec měl nakreslit rodinu a napsat své přání. Kresby se vyznačovaly nesouvislými čarami, které nebyly dokončeny, Tomáš využíval pouze černou a hnědou pastelku, kresby umistoval do dolní části archu. Rozbor pak sloužil dále psychologovi i sociální pracovnici. Sociální pracovnice Tomáše v průběhu hospitalizace pravidelně pozorovala, zaznamenávala projevy jeho chování (verbální i neverbální), působení Tomáše v kolektivu, motivační a hodnotový systém. Po přijetí Tomáše se snažila sociální pracovnice komunikovat s matkou, vést ji ke změnám v jejím přístupu k synovi. Velkým problémem byl i postoj matky, která trvala na svém a opakovaně se domáhala diagnózy autismu. Sociální pracovnice tak na základě několika jednání s matkou musela uvést, že matka není schopna spolupráce a výchovného vedení směřujícího ke stabilizace vývoje syna. Během pohovorů se u ní objevovaly konfrontační tendence, nekritičnost, vulgarizmy, útočnost. Sociální prognóza: Na základě všech získaných informací považuje sociální pracovnice dohled OSPOD nad výchovou a prospíváním dítěte po dimisi jako zcela nezbytný. Pokud matka nezmění přístup v péči o Tomáše, je doporučeno zvážit, 
zda by měl chlapec i nadále setrvat v rodině, protože aktuálně se jeví výchovné vedení chlapce matkou jako poškozující. Rovněž doporučena pravidelná péče v dětské a dorostové psychiatrické ambulanci.

\section{Závěr}

Sociální práce s dětským klientem je založena na spolupráci členů odborného týmu s cílem zajistit optimální vývoj dítěte vzhledem $\mathrm{k}$ charakteru a závažnosti jeho onemocnění. Základním cílem činnosti sociální pracovnice na dětských odděleních $P N$ je v prvé řadě zajištění veškerých dostupných informací o dětském pacientovi, zabezpečení sociálních potřeb dítěte po dobu hospitalizace, ale také přispět k nejlepšímu sociálnímu fungování dítěte s ohledem na jeho základní diagnózu. Tomu všemu přizpůsobuje styl a zpưsob sociální práce, přičemž je respektována autonomie dětského pacienta. Sociální práce má v péči o duševně nemocné dětské pacienty nezastupitelné místo.

\section{Seznam použitých zdrojů}

Cognet, G. (2013). Dětská kresba jako diagnostický nástroj. Praha: Portál.

Čevela, R. \& Čeledová, L. (2010). Výchova ke zdraví: vybrané kapitoly. 1. vydání. Praha: Grada Publishing.

Dobrušová, E. (2012). Sociálně-právní ochrana dětí v prípadech rozvodových a rozchodových konfliktů. Praha: Ministerstvo práce a sociálních věcí ČR.

Green, J. \& Jacobs, B. (1998). In-patient child psychiatry: modern practice, research and the future. New York: Routledge.

Gulová, L. (2011). Sociální práce: pro pedagogické obory. Vyd. 1. Praha: Grada.

Kutnohorská, J., Cichá, M., \& Goldmann, R. (2011). Etika pro zdravotně sociální pracovníky. Praha: Grada.

Kuzníková, I. (2011). Sociální práce ve zdravotnictví. Praha: Grada.

Marková, E., Venglářová, M., \& Babiaková, M. (2006). Psychiatrická ošetřovatelská péče. Praha: Grada.

Matějček, Z. (2001). Psychologie nemocných a zdravotně postižených dětí (3. přeprac. vyd). Jinočany: $\mathrm{H} \& \mathrm{H}$.

Matoušek, O. (2003). Metody a řízení sociální práce. Vyd. 1. Praha: Portál.

Matýs, J. (2014). Ambulantní psychiatrická péče o děti a dorost. Asociace dětské a dorostové psychiatrie [online]. [cit. 2016-11-04]. Dostupné z: http://www.addp.cz/clanek/ambulantni-psychiatricka-pece-o-deti-a-dorost.

Říčan, P., \& Krejčířová, D. (1995). Dětská klinická psychologie (2. vyd). Praha: Grada.

Sekera, O. (2009). Identifikace profesních aktivit vychovatelů výchovných ústavů a dětských domovů. Ostrava: Ostravská univerzita v Ostravě.

Spousta, V. (1995). Speciálně pedagogická diagnostika etopedická. Druhé vydání. Brno: MU.

Šnýdrová, I. (2008). Psychodiagnostika. Praha: Grada.

Vágnerová, M. (2005). Vývojová psychologie l.: dětství a dospívání. Praha: Karolinum.

Mahrová. G. (2006). Komunikace pro zdravotní sestry. Praha: Grada. 
Zacharová, E., Hermanová, M., \& Šrámková, J. (2007). Zdravotnická psychologie: teorie a praktická cvičení. Praha: Grada.

PORUCHY DUŠEVNÍ A PORUCHY CHOVÁNÍ (F00-F99). Ústav zdravotnických informacía statistiky ČR [online]. 2014 [cit. 2016-11-11]. Dostupné z: http://www.uzis.cz/cz/mkn/F00-F99.html

Theiner, P. (2009). Organizace psychiatrické péče o děti a dorost. In Psychiatrická klinika FN Brno [online]. [cit. 2016-11-04].

\section{Kontakt:}

Mgr. Dagmar Pitnerová, Ph.D.

Ústav pedagogiky a sociálních studií

Pedagogická fakulta UP v Olomouci

Žižkovo nám. 5, 77140 Olomouc

E-mail: dagmar.pitnerova@upol.cz

HRADILKOVÁ, Terezie a kol. Praxe a metody rané péče $v$ ČR. Průvodce sociálním modelem. Praha: Portál, 2018. ISBN 978-80-262-1386-4.

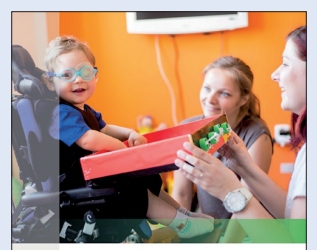

Praxe a metody rané péče $v$ ČR

Prủvodce sociálnim modelem

Terezie Hradiliková a kol.
Program rané péče provází rodiny, v nichž žijí děti s handicapem prvními týdny, měsíci a roky života dítěte. Raná péče představuje významnou pomoc těmto a pomáhá jim zprostředkovat nebo dokonce sama zajištuje komplexní služby v podobě psychosociální pomoci, rehabilitace, právní pomoci, podpůrných aktivit pro rozvoj dítěte. Tato publikace je určena především rodičům dětí s postižením a odborné veřejnosti, sociálním pracovníkům nebo studentům pomáhajících profesí.

Autorkou knihy je Mgr. Terezie Hradilková, která již 30 let působí v oboru rané péče, zakládala a řídila první střediska rané péče $v$ ČR - pro rodiny dětí s postižením. Zabývá se také problematikou kvality rané péče $v$ ČR i v zahraničí. 